\title{
WDRKING

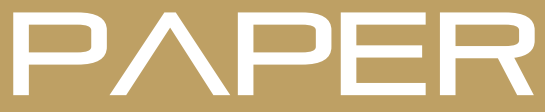

The municipal waste management sector in Europe: shifting boundaries between public service and the market

Barbara ANTONIOLI \& Antonio MASSARUTTO

\section{CIRIEC N N $^{\circ}$ 2011/07}


CIRIEC activities, publications and researches are realised with the support of the Belgian Federal Government - Scientific Policy and with the support of the Belgian French Speaking Community - Scientific Research.

Les activités, publications et recherches du CIRIEC sont réalisées avec le soutien du Gouvernement fédéral belge - Politique scientifique et avec celui de la Communauté française de Belgique - Recherche scientifique.

ISSN 2070-8289

\section{(C) CIRIEC}

No part of this publication may be reproduced.

Toute reproduction même partielle de cette publication est strictement interdite. 
Local public services: Facts, experiences and prospects

\title{
The municipal waste management sector in Europe: shifting boundaries between public service and the market Synthesis Report
}

\author{
Barbara ANTONIOLI* \& Antonio MASSARUTTO**
}

CIRIEC International Scientific Commission on « Public Services / Public Enterprises »

\section{Working paper CIRIEC $N^{\circ}$ 2011/07}

\footnotetext{
*University of Lugano, Switzerland.

${ }^{* *}$ University of Udine and Iefe, Bocconi University, Milano, Italy.
} 


\section{Abstract}

The aim of this paper is to make a comparative assessment of the industry organization in a selected number of European countries and understand the regulatory implications of the shifting of boundaries between market and public service domain. Using an institutional economic approach, focused on transaction along the value chain and on related governance mechanism, we will argue that: a) there is evidence of an increasing shift towards operator-based integrated systems; b) competitive tendering operates at best when these phases are kept separate; c) this requires a strong and efficient planning. More general remarks will be done about the actual presence of a European management model. Those results poses new challenges for economic regulation.

\section{JEL :}

Corresponding author:

antonio.massarutto@uniud.it

barbara.antonioli@usi.ch

\footnotetext{
"The speed of change within the waste management world has been faster in the last 10 years than the previous '90s, and the rate of change at the moment seems exponentially" (UK Chartered Institution of Waste Management, 2001).
} 


\section{Introduction}

The last 30 years have been characterised by an increasing quantity of waste, accompanied by a corresponding increasing difficulty to accommodate them (mainly due to a greater awareness of waste-related environmental issues).

The focus of waste management policies has gradually shifted from simple removal from the streets to planning of disposal, and further on to a more widespread policy aimed at governing material flows through the economy (Massarutto, 2007). Municipal waste management (MWM) has become to represent a service of public and general interest, a basis for civilisation, environment control and health protection; the public interest associated with MWM is not confined anymore to the dimension of urban propriety and public health, but is concerned on much more far-reaching sustainability issues: materials consumption, availability of disposal sites, pollution from treatment cycles, In the EU, these demanding environmental standards can be summarized in the transition to a new regime ("zero-landfill") focused on prevention, recycling and recovery prior to disposal, increasing convenience of valorisation (instead of landfill and incineration); an economic approach, focused on the polluter-pays principle and on extended producer responsibility (EPR) is a fundamental pillar of this strategy.

The shifting of policy priorities had major consequences on the organization of MWM services, the structure of its value chains and the related market failures and related governance issues.

The value added of the industry has been steadily growing; as a result, turnover and employment in the industry in Europe has increased significantly in the last 20 years. The European Union (2009) estimates that the size of the EU waste management and recycling industries accounts for a turnover of nearly 95 billion $€$, providing between 1.2 and 1.5 million jobs ${ }^{1}$.

The structure of the value chain has also significantly changed: while dominated in the past by collection services (labour intensive, low skill), it is now increasingly dominated by the downstream phases (treatment, disposal and recovery). The relative economic importance of each phase varies among countries; it is nevertheless remarkable that collection used to be by far the most important one until cheap disposal was available (around 90\% of the value added); this figure is now about $50-60 \%$ or less, despite the increase in the technical complexity of collection and sorting operations; this difference is

\footnotetext{
${ }^{1}$ Presidency Paper to the Environment Council on the fall in demand for recycled materials (February 2009).
} 
largely due to the increase of disposal costs, motivated by the need to control emissions and minimize resorting to landfill (Kaulard and Massarutto, 1997; Eunomia-Ecotec, 2003).

The concerned geographical scale of operations is also growing. While being a typical example of local utility, especially due to the bulkiness of waste and the incidence of transport costs, the waste sector today involves transactions at the regional, national and even global scale (EEA, 2009). Shipment of waste and trading of waste management services, while being obviously prompted by the unit value of materials, has nonetheless also important implications of law and order, since shipment to developing countries often masks illegal disposal, which is recognized as one of the most flourishing businesses in the hand of organized crime (Legambiente et al., 2005). This double-faceted reality can be understood if one considers that the concerned value that justifies waste trading is most of the times an "artificial" value arising from the costliness of legal disposal and treatment, or from obligations to recovery placed on industrial sector.

Finally, the actors that are active along the value chain are also much different from the past.

MWM has evolved from a simple blue-collar service dominated by collection, to a complex industrial activity focused on the post-collection phases (processing, recycling, disposal); this requires significant investment, division of labour, specialization, management skills and technological content.

At the same time, the interest of the private sector has also been rapidly growing. In the past, the private sector was represented mainly by external contractors to the local authority (mostly local small and/or medium enterprises, SMEs), performing labour-intensive activities, supply of landfill capacity (mostly from previously used quarries and mines) and supply of equipment (Ascari et al., 1992). Now, private operators are large integrated companies, frequently together with local authorities in Private-Public Partnerships (PPP). The scope for private sector involvement is much larger than in the past, since private companies do not only address the traditional low-value added and labour-intensive activities but also for the emerging high-value added ones: management and organization of the system, supply of specialized equipment, technological treatment (incineration, upgrading and selection of waste-derived materials, processing of hazardous waste), recovery of materials, consultancies (Buclet and Godard, 2000).

The size of MWM operators has been continuously growing and has, in some cases, reached a transnational dimension. The turnover of the top-15 companies 
in the European market alone accounts for almost 31 billion $€$; the top-3 companies alone - French multinationals Suez Environnement and Veolia, with the German Remondis, that has recently incorporated activities from the RWE group - alone represent a figure around 61\% of this total (Davies, 2003; Hall, 2009). This aggregated data does not make it possible to extrapolate MWM from the total amount of waste, but is surely indicative of a trend towards concentration and integration.

These transformations have major consequences on the patterns of industrial organization and on the regulatory regime, that the present paper aims at discussing. We provide a comparative analysis of the MWM market organization in a selected number of European countries, with the aim of understanding the common trends behind national specific features. Following the analytical grid presented in par.2, 8 national cases are presented (Italy, Germany, France, United Kingdom, Austria, Belgium, Sweden, Spain); specific features of each national market are analyzed in relation with the service organization, the nature of companies that populate the industry and the degree of openness to the private sector. The comparative analysis is based on the national papers prepared within the CIRIEC survey on local services (Dizy and Ruiz, 2010; Djemaci, 2009; Massarutto, 2010; Klien and Loser, 2009; Collignon and Gathon, 2010); a direct inquiry has been conducted on Germany and the UK. We'll show that, although moving from different starting points and different institutional settings, there is a common trajectory towards vertical integration (among phases) and horizontal integration (among management of waste flows that arise from different sources, e.g. municipal and business waste). We argue that this is motivated by the emerging economies of integration between collection, treatment and disposal, and is causing a real shift in the economic nature of the industry (market or public), calling for innovative regulatory arrangements.

\section{Focus of the study}

The present paper adopts an institutional economic perspective, focused on the analysis of the value chain of the MWM industry and of the governance regimes that characterize it. We follow Brousseau and Glachant (2008) in stressing the importance of the micro-institutions ensuring the governance of transactions, and deducing from these implications for economic regulation and public policy.

More precisely, our analysis builds on the theoretical understanding of the MWM industry already set out by Massarutto (2006). 
According to this interpretation, in the value chain of MWM we can identify three main phases that give rise to three distinct markets (fig. 1). The first one regards collection services, whose counterparts are waste producers and operators. The second is the market for the handling and disposal of waste, whose counterparts are operators of collection services and owners of disposal sites. The third is recovery/recycling, whose counterparts are again collection operators and final users of waste-derived materials. Within each market further additional secondary transactions take place, that identify additional side markets (eg. contracting out of specific activities from waste collection operators to specialized companies).

The chosen management solutions are framed within the European waste policy, whose main pillars are the ladder principle (choices should prioritize waste reduction, then reuse, recycling, energy or down-grade recovery); the selfsufficiency principle (waste should be handled as close as possible to its origin) and the polluter-pays principle (the polluter should bear the cost of his contribution to pollution).

Despite this relative uniformity, there is some room for flexibility and alternative solutions characterize different EU member states. Massarutto (2006) identifies 3 critical issues to be examined in order to characterize the economic regime of service provision.

The first one regards the size and scope of legal monopoly and related public service obligations. In the collection market, this concerns in particular which waste producers are obliged to join the public service or have the right to expect it to provide a solution, and which ones are free to choose the preferred supplier on the market (usually from a list of authorized operators). In the disposal and recycling market, instead, the issue regards the margins of freedom left to the waste collector to choose the preferred solution either on the open market or on the regional market (in case the SSP applies); and, conversely, the presence of universal service obligations placed on a regional disposal authority or a collective entity established in the recycling market.

The second issue concerns the coordination patterns between collection and disposal, separate collection and recycling. Coordination can be achieved directly through joint ownership (vertical integration), by long-term market transactions or via public planning. We expect the degree of competitiveness in the industry to be profoundly related to these patterns, in the sense that integrated solutions favour less competition in the market and tend to make private companies strive for larger dimensions and vertical integration.

The third issue regards the role and the scope of economic regulation, and the way this interacts with service provision and the market. This does not only 
concern prices, but also the designation of the obligations and risks, rights and duties of operators, the designation of responsibilities and related costs, with special emphasis on the appropriation of scarcity rents of disposal facilities and sharing of costs between waste producers (clients of the service), consumers (through the price of products) and taxpayers.

\section{A comparative assessment}

\section{$\underline{\text { Common features and national specificities }}$}

The comparative analysis of the 8 countries reveals some important basic features common to all countries, but also important national specificities.

All countries have proceeded along a similar evolutionary path, whose phases can be traced in fig. 2. Along this path, the focus of policies change (from simple removal of waste to planning of disposal and managing the material flow), with an associated shift in terms of key actors, key words and managing solutions (tables 1-2).

The implementation of the EU principles (priority ladder prioritizing reduction of waste, reuse, recycling, recovery; minimization of disposal and especially landfill, reserved only as a last-resort opportunity for materials that cannot be valorized) is proceeding at a varying speed.

Waste quantities have been increasing dramatically in the last 20 years; in some countries this trend seems now over, and signs of an inversion of sign can be noticed, even if it is probably too early to predict that a full decoupling between economic growth (GDP) and waste production has been genuinely achieved.

Landfill diversion has been significant in all countries between 1995 and 2005, with Italy leading (-39\%); yet its very elimination has been achieved quite completely in Austria, Belgium, Sweden, Netherlands, Germany; while Italy, UK, France and Spain are still landfilling a significant part (40-50\% or more). Landfill diversion has been achieved through a combination of strategies, that includes a variable mixture of direct recycling, indirect material recovery (compost, RDF) and waste-to-energy. From the summary data shown in table 3, significant diversion rates can be achieved only where all of these strategies are

combined, while strategies concentrated on sole recycling, despite some success at the local scale, do not seem to be able to perform at the scale of the overall system. 
Competing regimes: public service and market

In all countries we find the contemporary existence of two competing institutional regimes (fig. 3).

On the one side, we have the public service regime, that applies to household waste, orphan waste (street cleaning etc.) and a fraction of commercial waste, varying from country to country, whose producers are also associated to the public service. The public service is organized as a legal monopoly and entails the definition of a public body responsible to deliver the service (usually municipalities, alone or associated) and an obligation of producers to use the service according to the prescribed regulation.

On the other side, we have the market regime, applying to the remaining of commercial and business waste. Here the responsibility is placed on the producer, who discharges this responsibility by consigning waste to an authorized operator. The public sector in this regime acts basically as quality regulator, defining standards to be respected, norms regulating shipment of waste, authorizing operators and treatment facilities.

The boundary between both regimes is permeable, and the scope of market and regulated activities changes significantly from one country to the other. Nevertheless, some important changes have occurred, modifying in a substantial manner this traditional segmentation.

The first change concerns treatment and disposal of municipal waste. While in the past the collector of municipal waste could purchase treatment and disposal directly on the market, this came out not to be true early in the 70s, justifying an enlargement of the scope of waste policy, in order to include disposal.

Not all countries have felt the necessity to extend public service obligations to treatment facilities, but most of them have made steps in this direction.

In particular, legal monopoly is universal for collection, while disposal is sometimes under the responsibility of the collection authority (having to find a solution on the market as the owners of other categories of waste), and sometimes under a dedicated authority that has an obligation to guarantee the service at a larger territorial scale. In the latter case, the disposal authority may be just a last resort solution in case collectors are unable to provide themselves, or be a legal monopolist having the right to dispose of all waste produced in a given territory and to set the prices (in this case following regulations established by public powers).

Sometimes (Sweden, UK) authorities set up at the regional level assume (legally or de facto) responsibility to put in place treatment capacity, or at least to act as last-resort providers in case municipalities cannot find a solution themselves; the initiative of public sector leads often to the creation of own treatment and disposal companies, like the LAWDCs in the UK. In other countries (Italy, Germany, Austria) the regional plan has more the task of coordination, but this usually entails also the stimulus to the initiative of local authorities in the 
creation of own capacity; this has led sometimes to the creation of intermunicipal companies focused on treatment, that later on extended their operation also to collection services, ultimately leading to vertical integration. In still other cases (Spain, France) the system on the demand side is similar, yet the supply side is dominated by private companies.

We can advance the hypothesis that a significant change occurs once the system evolves from a technological approach dominated by disposal of waste in landfills, to one trying to maximize diversion from landfill, and requiring therefore a more complex industrial value chain downstream of collection. In figure 2 and table 1 we can notice that in the post-landfill regime, flows of waste from both sectors become important, and new institutions aimed at governing the related transactions arise (e.g. the entities created under the extended producer responsibility scheme). While in the former regime the focus was mostly on the origin of waste (municipal vs. commercial), in the emerging regime it seems to be placed on destination (recyclable vs. ultimate waste), in the sense that valorization opportunities (either direct recycling, other forms of material recovery or energy recovery) are increasingly found on the market, and more and more at a geographical scale that is becoming national if not paneuropean, especially for materials that are less bulky, easier to mobilize and entailing higher unit value.

$\underline{\text { Regulation, planning and operation }}$

Three different layers of policy can be distinguished:

- national policies, mainly focused on material balance and economic, technical and environmental regulation;

- regional policies, focused on planning of disposal capacity and overview of management practices;

- local policies, focused on the organization of services aimed at an effective waste removal.

Given that disposal seems to be the most important problem - currently and in the next future - as a consequence, the regional regulation has assumed a crucial role.

Whereas in all countries a planning system is foreseen by legislation and more or less implemented, the scope of planning varies both between countries and during time. In some countries (Italy, Germany, Sweden in particular) regional planners used to be directly involved in the choice of technology, size and location of facilities, even sometimes ownership and management of disposal services; in turn, in France and the UK planning is mostly concerned with supervising and ensuring that an overall adequate capacity is in place, without interfering too much in investment choices. Again in all countries the trend goes in the direction of increasing the direct responsibility of waste collectors on disposal, treatment and recycling choices. 
Local authorities, often associated, continue to have a central role in MWM policy.

Two basic schemes can be identified. In the first scheme, collection and disposal authorities hold separate management agreements, either in-house or contracting out. This solution implies that the disposal authority has to actually decide which disposal solutions to adopt and play a more active role in the strategic decisions concerning service organization; on the other hand, it makes contracting out of separated activities easier. Private counterparts of the public sector are typically local SME, while disposal, once generally purchased from the local market, is owned and directly controlled by local authorities as soon as scarcity rents begin to appear.

The second scheme entails a single arrangement for the whole service with the same integrated company. This scheme is seemingly increasing its importance. Planning played a fundamental role in the infancy phases of the disposal industry, and especially once the transition from landfill to more modern solutions had to be coordinated, but also revealed weaknesses (eg excess of supply, inadequate technical choices, poor coordination with collectors' strategies). The more mature the market becomes and the more professional management is needed, the more planning leaves space to operator-based integrated systems, with planning mainly limited to the definition of targets, regulation and, eventually, provision of last resort solutions when emergencies occur. This development is clearly correlated to the increase - both dimensional and in the scope of activity - of the role of the private sector. The prominent figures are large companies, either heirs of previously established local public multiutilities (Italy, Germany) or specialized professional firms, often multinationals, and sometimes resulting from the transformation of local companies starting the waste business from landfill operation; PPPs, mergers and outsourcing are also frequent. At this level some competition occurs (eg for the selection of partners in the PPPs, less frequently for the whole concession), but it is for sure much weaker. Tenders are most often "beauty contests" leaving substantial discretional power to the awarding authority.

In all cases, public responsibilities on collection and/or disposal can be fulfilled via several options ranging from direct management (in-house companies) to full delegation. Municipally-owned enterprises have a long tradition in Italy and in Germany through a very wide spectrum of public/private-law solutions. This variety is somewhat reducing now, with an emerging predominance of private law arrangements. In the meanwhile the UK has introduced the possibility to create LAWDCs, possibly evolving towards the PPP structure.

Tendering is sometimes compulsory even when in-house solutions are finally chosen (eg in the UK, and in Italy, when the in-house option will become the exception and competition for the market the rule), while in other countries municipalities are obliged to tender only when they wish to involve third parties; this obligation has been introduced only recently, to face pressures from the European institutions claiming against the potential abuses and discriminations. 
This phenomenon has particularly affected PPPs: repeatedly, the European Court of Justice has denied legitimacy to the direct entrustment of MWM contracts to already established companies, on the basis that PPPs should be created ad hoc for each specific transaction and after a competitive tender for selecting private partners (Hall, 2006).

Depending on how successful local authorities have been in ensuring treatment of all residual waste that remain under their responsibility, regional authorities are also in charge for providing last-resort solutions in the emergency. In Italy, some regions have developed a multi-layer organization, stimulated by landfill taxes: local authorities that are unable to find a solution may resort to the upper level, but have to pay a higher charge (plus, in general, higher gate fees).

Although trading of waste is still more an exception than a rule, often facilities have spare capacity that is sold on the open market once fulfilled the obligations assumes with local municipalities (either arising from long-term contracts and vertical integration or from authoritative planning decisions).

Trading is more relevant, nevertheless, once secondary materials aimed for recycling (or downcycling) are concerned. In accordance to the EU principles forbidding "waste tourism" but allowing the shipment of materials that can be valorized, including combustible waste -

Also, it is important to notice that a significant quantity of materials that are theoretically aimed for recovery are traded even when a market cannot be found - either because they can now be legally defined as industrial waste, or because it is not overall clear where the boundary stays between true disposal and many sorts of "downcycling", such as the use of treated waste for road and railway pavements, construction industry or rehabilitation of contaminated sites. Although the legal framework provide a definition of this boundary, this seems to be often conventional and open to abuse.

All these examples show that there is an increasing quantity of waste moving from one to the other regime: many waste materials arising from the public service regime are traded to the market regime for recovery, while the commercial waste system originates residual waste that needs to be disposed of.

\section{Extended producer responsibility and compliance schemes}

A major change that takes place in all countries regards the recycling sector. Until recycling played a residual role, it has remained fundamentally a market activity, driven by the private interest of recyclers and limited by the very low market value.

Following the EU strategy, recycling has acquired a completely new role; the (potential) economic convenience has been boosted by the increase in the cost of traditional disposal, but encountered a bottleneck in the limited industrial capacity. 
The main driver of change has been the adoption of the EPR principle, leading to the creation of compliance schemes funded by industry and responsible for achieving recovery targets. Initially, these schemes have operated as monopolies, either legally established (like in Italy, where adhesion is compulsory and charged with a mandatory fee that is practically a tax) or de facto (as in Germany or France, where the market power of DSD and EcoEmballages was guaranteed by the dominant position on the market of their sponsors).

Monopoly operators had normally a sort of a public service obligation (e.g. offering a framework contract to all collectors of separated waste). Later on, this market structure has evolved towards a more competitive one; in most countries producers can choose to adhere to competing compliance schemes (or even to reach the target themselves), while compliance schemes negotiate directly with municipalities. In some cases (e.g. France) the situation is mixed, with some compliance schemes acting as residual players offering a basic contract to all, and others that operate on a free market base and can offer alternative solutions. All in all, these experiences lead us to conclude that until recycling capacity remains a bottleneck, a monopolist responsible entity providing guarantees both of the recovery of separate collection costs and investment in recycling capacity is still needed, at least as a last-resort umbrella. It is remarkable to note, instead, that these systems have been very effective in promoting recycling and "compete" with disposal facilities for receiving waste flows.

Once the market has developed and the recycling industry has developed, in turn, it is less justifyable to maintain a strict legal monopoly in this phase.

\section{$\underline{\text { Finance and economic instruments }}$}

While the value added of the MWM industry is clearly booming in all countries, sources of financing for the sector have also experienced important transformations.

The total cost is basically shifted between three channels. The first one (important in the past, now residual) is represented by the public budget funded by general taxation. The second one is represented by the service charges paid by waste producers (the citizens) to service providers, either directly (through tariffs and charges) or indirectly (through local taxes raised by municipalities and later on earmarked to service providers). The third one, whose importance is increasing, is represented by those costs that are internalized by industry and charged onto consumers via product prices.

The relative share varies in dependence of two basic factors.

The first one concerns the way responsibilities are shared between service providers and EPR-based compliance schemes. In Germany, for example, the latter are organized so as to bear the full cost of the "dual system", including separate collection. In most of the other countries, these systems bear only the 
differential cost (namely, the additional cost that municipal operators encounter with respect to other ways of treating waste. Therefore, the different costs of compliance schemes to industry cannot be interpreted as depending on relative efficiency.

The second one concerns the system of economic incentives put in place with the aim of discouraging other forms of disposal (eg taxes on landfill and/or incineration). Landfill taxes are adopted in most countries; the highest fares can be found in the Netherlands $(85 € / t)$, while Sweden, Austria, Belgium and recently the UK have set it at values above $40 € / t$. In Italy, France and Spain it is in the range of $15-25 €$.

All countries seems to be oriented to the implementation of the polluter pays principle. The latter, an important principle of environmental policy, has also important fallout on financing and efficiency. It means that the polluter should bear the expenses of carrying out the cost of polluter prevention and control measures. In other words, the cost of these measures should be reflected in the cost of goods and services which cause pollution in production and consumption; such measures should not be accompanied by subsidies that would create significant distortions in trade.

Financing is shifting from traditional, direct charge levied by municipality on a cost-recovery base to tariff paid directly to operators and to an economic incentive approach ${ }^{2}$.

Service charges were traditionally levied as earmarked local taxes, usually on the base of the value of properties or similar indicators. Nowadays, the movement towards pay-for-service charges is widespread and generalized. While sometimes calculated on the base of standard indicators (thus with little or no incentive potential), incentive charges are also increasingly diffused, although using rather different schemes (pay-per-bag, per container etc.). Often these schemes entail cross subsidies that favor recycling (low or no charges for separate collection) at the expenses of unsorted waste, on which most of the charge is concentrated.

\section{$\underline{\text { Role of private sector }}$}

The involvement of private bodies is differentiated in terms of typology, size and focus of the firms. They were initially engaged in collection with concession by local authorities; afterwards they enter the market for disposal, recycling and recovery - usually free market instead of legal monopoly - , alone or by the participation to PPP with public firms (the most typical way to penetrate foreign markets). The preference is for large integrated companies and for (corporate) privatization of public companies. In general, their increasing role is in part

\footnotetext{
${ }^{2}$ In particular, the trend is from tariff structure on purely fiscal base (also common with other services) to tariff structure normally volumetric or fee-for service.
} 
referable to the correspondent increasing need for private financing, as well as high level skills.

On the other hand, the weight of the private sector in each member state varies significantly, depending on the national patterns of organizing the service and different contractual arrangements. Our analysis does shows only marginal variations with respect to the one provided by Saint-Bris, 2003 (fig. 1). Private sector involvement includes a wide range of solutions, from outsourcing and delegation to open market, from PPP to project financing.

Figure 1 - Fraction of the market outsourced to private companies in some EU countries

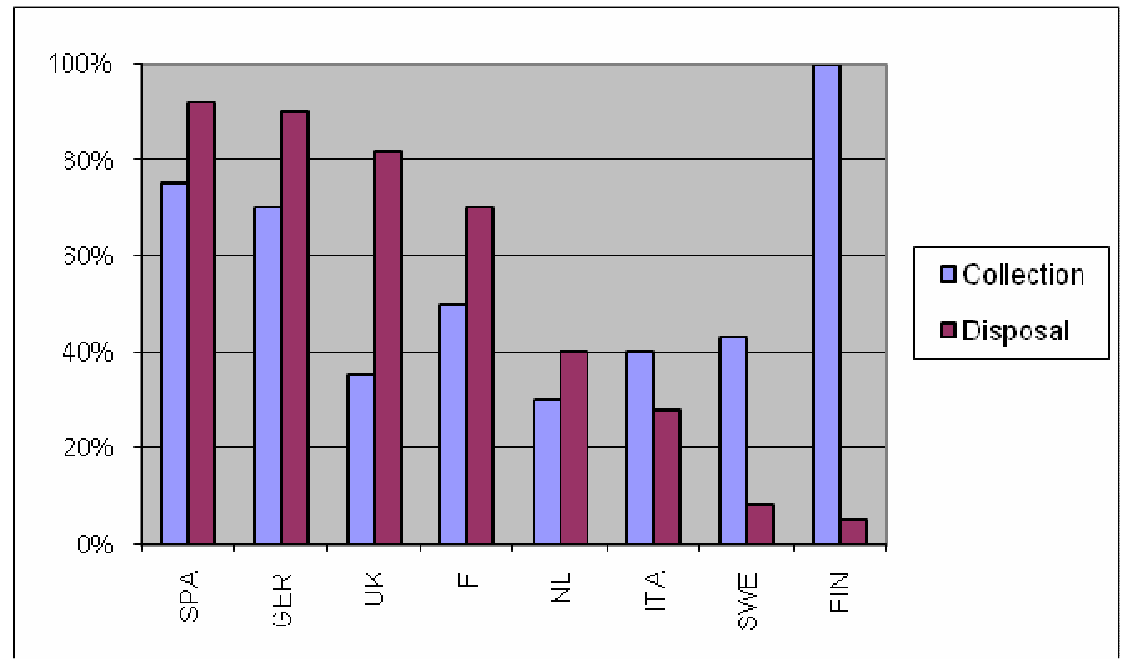

Source: based on Saint-Bris, 2003

A first overview can be offered through an analysis of the ownership and organizational structure of the operators to which municipal services are entrusted.

Direct labour organizations still exist in many countries, but play a residual role, mostly concerning small municipalities.

Public management is more often organized through corporate structures, either under public or more frequently private law establishments. In some countries (notably, Italy and Germany) some of these companies have evolved towards a corporate model, growing through mergers and often proposing later on onto the open market, either participating to tenders and PPPs in other regions, or by selling specialized services (eg treatment) to other undertakings.

Delegation to the private sector is also diffused everywhere, but with higher market shares in Spain and in France. PPPs are in place especially in the field of complex industrial treatment facilities (incinerators, mechanical sorting).

As Hall, 2006 shows, although the industry concentration is still not very high, there is a bunch of companies whose operations are now consolidated in the 
wider European market. Companies like the French majors (Véolia and Suez), or the german Remondis can be identified as the market leaders; they operate in other countries either by entering in agreements directly with municipalities in PPP projects (especially in the field of industrial treatment) or by buying shares of already existing operators.

This picture, however, captures only the surface. In most cases, public undertakings do in fact contract out a significant part of their activities to private contractors under management contracts or outsourcing of phases. Therefore, together with big players we can also identify a large number of smaller companies, often operating at the national or regional level, providing a full range of specialized activities: from separate collection to production of containers and equipment; from $\mathrm{R} \& \mathrm{D}$ to innovative recycling solutions; from marketing of recyclables to the recovery of "downgraded" materials.

As we have seen, in the "old regime" there is a strong separation between public sector and market domain, with very little opportunities for trade. Otherwise, with the new model the focus of public service shifts from municipal waste to residual waste - all that remains after sorting, processing and treatment for recovery - , with increasing opportunity for trade. Again, there could be two alternative institutional schemes for the public service: separated or integrated. The former consider two autonomous entities responsible for collection and disposal, as well as the contracting out to specialized companies under various schemes such as tender, PPPs, DBFO. With the latter there is only one single entity responsible for collection and disposal; the service is managed under a regulated monopoly or a de-facto monopoly if tendered.

Be these companies fully and genuinely private or do they originate from the transformation of public companies previously established as in-house operators, they seem to keep away from sunk costs in the local markets they serve. Activities entailing large sunk capital investment are typically shared with local public authorities, while those involving a significant presence on the territory are subcontracted to local SMEs. An innovative pattern of division of labour can be postulated, with local (public) actors having a competitive advantage in activities requiring sunk costs or where having deep roots in the territory and a reputation of stewardship and faithfulness to local exigencies is a prerequisite of success (this often applies, for example, to the location of facilities). All other industrial tasks will instead undergo further market consolidation, both entailing the increase in the market share of large players and the development of specialized enterprises along the value chain for the different activities (from equipment to intermediation, from research to the development of innovative recycling solutions). 


\section{$\underline{\text { Regulatory implications }}$}

After the identification of common features, it emerges the need for a more detailed analysis aimed to pick out differences and critical issues beyond similarities.

\section{- Transition towards maturity: obstacles and pitfalls}

In this changed background, industrial management alone seems to be no more sufficient; this could justify the grown of delegation to professional operators, keeping and strengthening the centrality of public participation.

Again, there is a need for a phase out of landfill, but in several cases markets has failed in the development of alternative solutions, also due to strategic behavior of landfill owners. There could also be a trade off between the risk of excess of supply (eg. Germany) and the risk of "blackout" (eg. Napoli).

Finally, we have to pay attention to possible grey zones between recovery and disposal markets, with potential spillovers and case for illegal activities.

- Integration or separation of responsibility?

As we have seen, in some case there are two separate authorities responsible for collection and disposal while in other we can find only a single authority - with a corresponding single contract - responsible for both. If this could sketch out different management models, in both cases the result seems to be a more concentrated industry, where disposal authorities and planning becomes a last resort opportunities. Integration with the recovery market is a key to corporate success, but this also implies a lower degree of competition, since owners of disposal and treatment facilities can very easily prevail.

Many countries have engaged in competitive exercises, but their success is limited. Compulsory competitive tendering has been successful for specialized phases (collection or treatment as separate activities), but at this level competition is far less successful. Tenders are based on discretional awarding criteria (the "best value" in UK, national variations of the "competitive dialogue" again in the UK, France and Spain) and in most cases the number of bidders is small (one or two). This evident trade-off suggests the need to adopt regulatory structures that are more targeted at countering the market power of these "de facto" monopolies.

- Market power in several phases of the value chain

In the management of the core system, an important value added that strengthen market power is represented by the "territorial entrenchment". Local - usually public and integrated - firms, as well as their evolution, the local public group, have strong, historical roots in the territory, with negative fallout in terms of contestability of the market; potential leaders must have the capacity to raise consensus locally. In several cases the strategy adopted by non-incumbents 
private operators to enter into the market is to create a public-private partnership with public bodies.

Also the market for recovery is characterized by a certain degree of market power: all countries considered (except UK) started with a monopolist compliance system, with mandatory adhesion, at least de facto. Various attempts to develop more competition reveal strong economies of scope between CS (intermediaries) and the industrial phases, economies that also in this case limit the market contestability.

- Towards an "asymmetric side-competition"?

Public service obligation has become a last resort opportunity for all waste that cannot find a destination in the recovery market. In other words, all waste that is not collected separately has to be received by the public system, as well as waste to which the collector is unable to find a destination. This imply an increasing development of recovery and recycling markets; after a start-up phase, those ones are more and more interested by attempts to create conditions for competition.

While disposal remains as a last resort option, the economics of disposal becomes more challenging. Enough disposal capacity should be in place, but all efforts are concentrated to minimizing its role. Since disposal facilities ultimately imply a fixed and sunk cost, it could be recommended that managing of residual waste is conducted with a public service obligation, for which some compensation (in terms of guaranteed revenues) should be ensured. In turn, if this compensation is searched for by ensuring a legal monopoly on local waste to facility operators, this might weaken the incentives to engage in recycling and separate collection. As we have argued elsewhere (Massarutto, 2006) this dilemma could be solved by ensuring that some competition among facilities is created, through a relaxation of the self sufficiency principle once a minimum of capacity has been put in place.

\section{Concluding remarks}

The evolution sketched above opens some interesting issues that in our opinion will represent the main regulatory problems to be dealt with in the next future.

The first one concerns the vertical structure the industry is assuming. As we just noticed, key operators are most typically large companies operating at the national or possibly international scale, having the necessary size, professional capabilities, financial guarantees, technical expertise, reputation and capacity to organize and govern transactions with more specialized operators along the value chain.

If this forecast is correct, it will raise interesting questions about the second issue, that is the best available regulatory solutions to be adopted in the emerging vertically integrated and (at least partially) privatized legal monopoly 
for collection and disposal. The solutions that are recommended both by the Oecd (2000) as well as by European institutions and national governments fundamentally based on the idea of "competition for the market" do not seem the most appropriate, since competitive tendering is not easily practicable at the stage of the integrated service; even if tenders do actually occur, they cannot be based on simple performance parameters and require careful specification of both quality performance and post-award renegotiation. Barriers to incumbent replacement in the next bids are high. In fact, the only way to impede monopolization of the market is to contract out single activities instead than integrated management, what in turn requires that public sector is able to perform this task effectively. The trend in the market is clearly in the opposite direction. If this is the case, we believe that innovative regimes based on yardstick competition, price regulations, environmental and quality certification are more suitable and should introduced at least as a complementary tool even where tenders are mandatory.

The third is strictly related to the previous one and concerns the difficult and conflicting relation that this pattern of development is having with the emerging regulatory style at the European level. The EU has started a policy in this field that limits substantially the degrees of autonomy left to public powers in the choice of management solutions. The main concern seems to limit the possibility that public undertakings become market competitors, exploiting the advantages and privileges obtained in the home market in order to subsidize expansion to other markets. For this purpose, public authorities are allowed to avoid competitive tendering only when the operator fits the very stringent definition of "in-house provision" (European Commission, 2004). PPPs should be intended as alternative ways for ensuring the fulfillment of a particular public service obligation and not as a way to create autonomous enterprises (European Commission, 2005a). Finally, public service obligations that justify the institution of a legal monopoly should be spelled out in detail and compensated on a strict direct cost base (European Commission, 2005b).

In fact, it seems quite evident that many of the actual players in the MWM market are in some way deriving from already established local utilities. PPPs in many cases are the result of complex and sophisticated aggregations of incumbents rather than being mere substitutes for delegation and direct management. The dynamic process of consolidation is still in course especially in countries such as Italy and Germany, where the tradition of locally owned public enterprises has stronger roots. In these countries, applying too rigidly the European philosophy generates the risk of favoring indiscriminately large multinationals.

Fourth, and finally, the emerging regime has very unclear potential outcomes on the equilibria characterizing other market segments such as those concerning industrial and commercial waste - strangely enough, one of the least-known and less regulated sectors of the economy. As far as the local markets are dominated by a powerful business-oriented incumbent holding legal or de-facto monopoly 
over household waste, its capacity to compete successfully in the other waste markets becomes apparent. Operating as a monopolist in the MWM allows a substantial market advantage, especially when there is capacity in excess that can be sold freely on the open market. Landfilling of ultimate waste offers a further opportunity, since facilities that are authorized for this purpose are normally the same as for commercial and industrial non-hazardous waste, and share a similar regulatory regime.

\section{References}

ADEME, 1999, La gestion des déchets en France : les évolutions essentielles depuis 1992.

Arcadis and Eunomia, 2008, Optimizing markets for recycling, European Commission DG Environment, http://ec.europa.eu/environment/enveco/waste/pdf/optimising_markets_summary.pdf.

Bertossi P., Kaulard A., Lolli A., Massarutto A., 1996, "Per una nuova politica industriale nel settore dell'igiene urbana in Italia", Economia delle fonti di energia e dell'ambiente, n.3.

Bertossi P., Buclet N., Fischer L., Kaulard A., Massarutto A., 2002, The dynamic effects of interactions between national regimes: towards harmonisation, in Buclet (ed.), 2002.

Brusseau E., Glachant J.M., 2008, New Institutional Economics: a guidebook, Cambridge University Press, Cambridge, UK.

Buclet N., ed., 2002, Municipal waste management in Europe: European policy between harmonisation and subsidiarity, Kluwer, Amsterdam.

Buclet N., Hafkamp W., Lupton S., Petschow U., 2002, Interactions and main sources of friction between national regimes, in Buclet (ed.), 2002.

Buclet N., Fischer L., Hafkamp W., Petschow U., 2002, Three scenarios for the organisation of MSW management in Europe, in Buclet (ed.), 2002.

Buclet N., Godard O., a cura di, 2000, Municipal waste management in Europe: a comparative study in building regimes, Kluwer, Amsterdam.

Cima S., Sbandati A., 1999, L'economia dei rifiuti solidi urbani, Franco Angeli, Milano.

Collignon A., Gathon H.J., 2010, Les déchets en Belgique, CIRIEC Working paper 2010/09.

Davies S., 2001, Mergers and acquisitions in the European waste management industry 2000-2001, Public services international research unit, University of Greenwich (www.psiru.org).

Defra, 2005, Review of Local Authority Waste Disposal Companies and Their Role in Future Procurement. 
Defra, April 2006, Guidance on the Recycling Credit Scheme.

Defra, 2010, Consultation on implementing the packaging strategy, http://www.defra.gov.uk/corporate/consult/packaging-regs/index.htm.

DETR, 1998, Local Government PFI in England - Criteria for Allocation of PFI Credits, December, www.local.detr.gov.uk/pfi/index.htm.

Dizy D., Ruiz O., 2010, The Spanish Waste Sector: Waste Collection, Transport and Treatment, CIRIEC Working paper 2010/03.

Djemaci B., 2009, Public waste management services in France. National analysis and case studies of Paris, Rouen, and Besançon, CIRIEC Working Paper 2009/02.

Ecotec, 2002, "Analysis of EU eco-industries, their employment and export potentials", EC, DGEnv, http://ec.europa.eu/environment/enveco/industry_employment/main_report.pdf.

Eunomia-Ecotec, 2003, Costs of municipal waste management in the EU, Report to the EC-Dg Env, http://ec.europa.eu/environment/waste/studies/eucostwaste_management.htm.

European Commission, 2004, White paper on Services of general interest.

European Commission, 2005a, Communication to the European Parliament on privatepublic partnerships and procurement.

European Commission, 2005b, Decision of 28-11-05 concerning the application of art.86 par. 2 of the EC Treaty concerning State aids under the form of compensation of public service obligations.

European Environment Agency, 2009, Waste without border. Transboundary shipment of waste, EEA Report 1/09, EEA, Copenhagen.

Horváth T. M., Péteri G., 1996, Management of local Communal Services, in Market Competition - Contract. Management and Financial Methods in Municipal Communal Service, LDI Foundation, Local Government Know-how Programme, Budapest.

Kaulard A., Massarutto A., 1997, La gestione integrata dei rifiuti urbani: analisi dei costi industriali, FrancoAngeli, Milano.

Klien M., Loser P., 2009, Austrian Waste Sector CIRIEC Working Paper No. 2009/10. Legambiente and CCTA, 2005, Rifiuti Spa. Radiografia dei traffici illeciti, http://www.legambiente.com/documenti/2005/0125_rifiutiSpa/rifiuti_spa.pdf.

Lehmann A. M., Private Institutions in Waste Management Policies Between Markets and Structures of Corporate Governance, mimeo.

Lehmann A. M., 1999, Private Institutions in Waste Management Policy and Their Antitrust Implications. The Case of Germany's Dual Management System, mimeo.

Massarutto A., 2002a, La regolazione economica e finanziaria dei servizi ambientali: acqua e igiene urbana, in L.Robotti, a cura di, Competizione e regole nel mercato dei servizi pubblici locali, il Mulino, Bologna. 
Massarutto A., 2002b, "Dalla tassa alla tariffa: cosa cambia veramente per il finanziamento del settore dei rifiuti?" Economia delle fonti di energia e dell'ambiente n. 1 .

Massarutto A., 2007, Economic analysis of waste management systems in Europe, in C. Clini, M.L. Gullino, I. Musu and X. Yang (Eds.), Sustainable Development and Environment Management - Experiences and Case Studies, Springer, NL, pp. 171-186, ISBN978-1-4020-6597-2(HB), ISBN978-1-4020-6598-9 (e-book) Language: English, Chinese.

Massarutto A., 2010, Municipal waste management in Italy, CIRIEC Working paper 2010/01.

OECD, 2000, Competition in local services: Solid Waste Management.

OECD, 2006, More competition, less waste. Public procurement and competition in the municipal waste management sector.

Perra L., 2000, Rifiuti solidi urbani: un'analisi economica dell'assetto produttivo, Working Paper 00/34, CRS Proaqua, Roma (http://www.proacqua.it).

Poli C., 2002, Le strategie di risposta delle imprese operanti nella filiera idrica e nell'igiene urbana, in Vaccà S., a cura di, "Problemi e prospettive dei servizi locali di pubblica utilità in Italia", FrancoAngeli, Milano.

PSIRU, 2003, European waste management: background to a discussion on EWCs: Waste management companies in Europe.

Szymanski S., 1996, "The impact of compulsory competitive tendering on refuse collection services", Fiscal Studies, vol. 17 n. 3, 1-19.

Waste Management Council (AOO), 2003, The waste market: the Netherlands and neighbouring countries, http://www.afvalscheiding.info/images1/aoo_nl/bestanden/AOO2003-12.PDF.

Watson M., Bulkeley H., Hudson R., 2004, Vertical and horizontal integration in the governance of UK, draft paper. 
Figure 1 - Primary, secondary and tertiary markets in the value chain of SWM

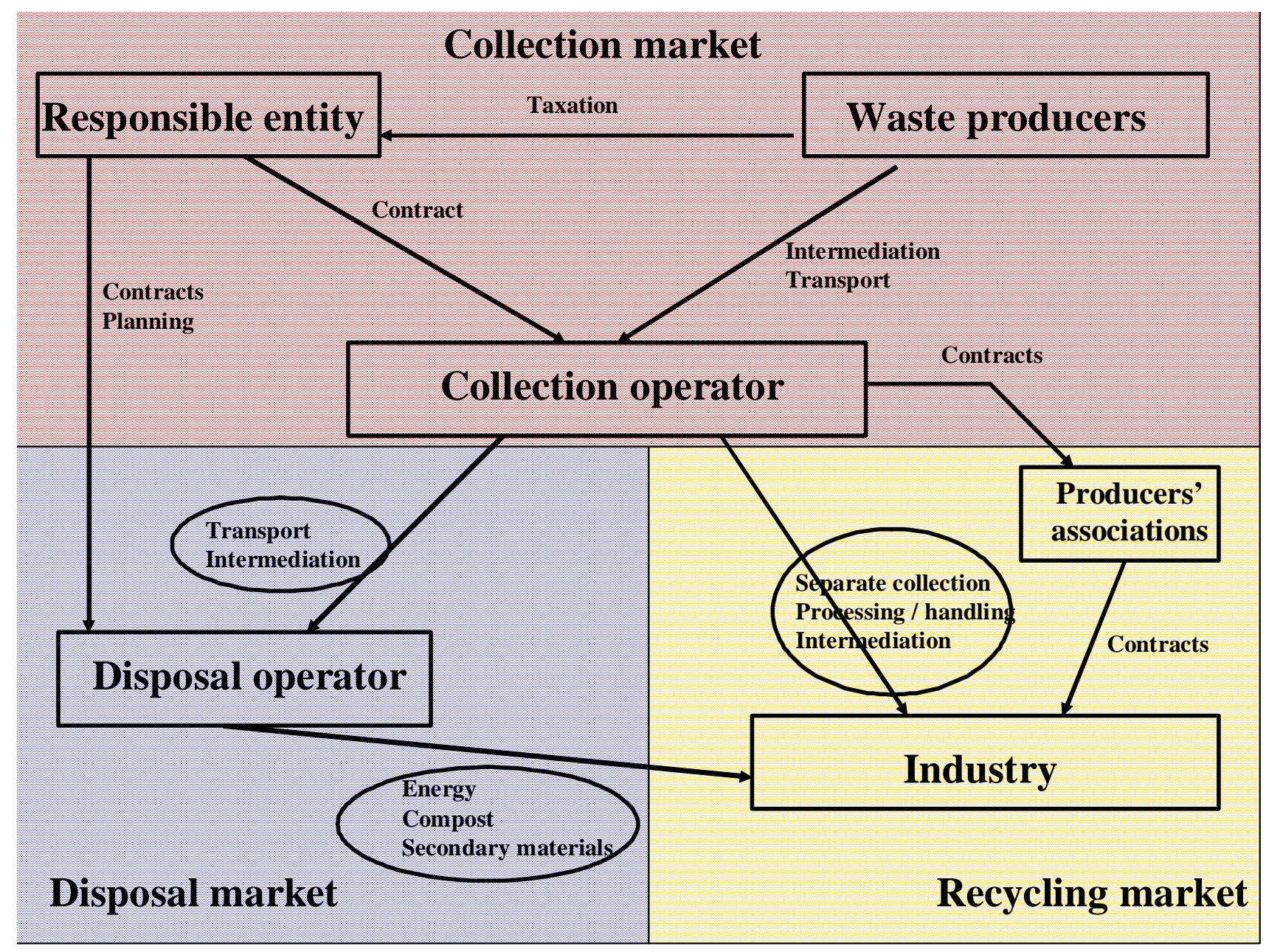


Figure 2 - A short history of waste management policies in Europe

Waste policy does not exist (before '50).

No problem. All waste generated is either reused or simply thrown away.

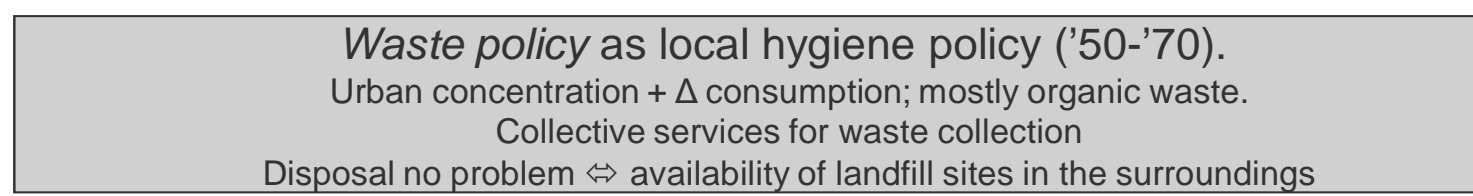

End-of-pipe regulation ('70-primi '80).

Externalities from disposal start to emerge

Shortage of available facilities

Lifestyle change $\Leftrightarrow$ Dramatic increase of quantity of waste and potential hazards

Regulation of the impact of disposal facilities (mostly command and control)

Prevailing regime: authorization + residual markets for secondary materials

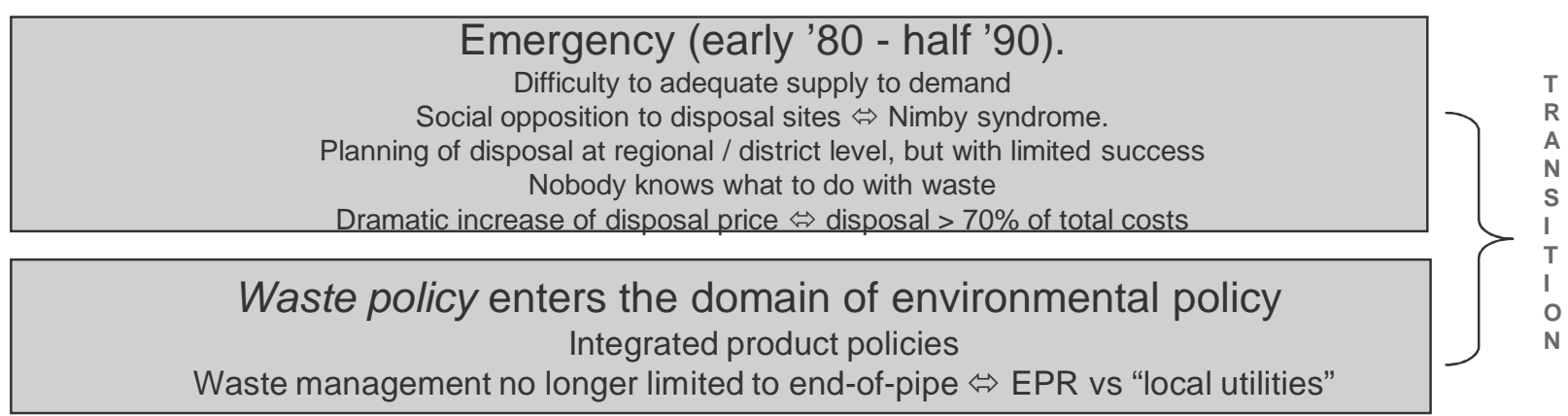


Table 1 - Evolution of waste management regimes

\begin{tabular}{|c|c|c|c|}
\hline Regime & Main objective & Key actor & Emphasis on ... \\
\hline Public hy giene & \multirow[t]{3}{*}{ Removing waste from urban areas } & \multirow[t]{3}{*}{ Municipality } & Quality of service \\
\hline \multirow[t]{2}{*}{ (- end 60s) } & & & Urban propriety \\
\hline & & & "Out of sight, out of mind" \\
\hline $\begin{array}{l}\text { Environmental } \\
\text { protection }\end{array}$ & $\begin{array}{l}\text { Minimizing environmental impact of } \\
\text { disposal }\end{array}$ & \multirow[t]{2}{*}{ Legislator } & Technology \\
\hline (early 70s) & $\begin{array}{l}\text { Avoid shipments of waste towards } \\
\text { low-standard countries }\end{array}$ & & End-of-pipe regulation \\
\hline $\begin{array}{l}\text { Facing the waste } \\
\text { mountain }\end{array}$ & \multirow[t]{3}{*}{$\begin{array}{l}\text { Ensuring adequate disposal capacity } \\
\text { face to dramatically increasing } \\
\text { quantities and supply shortage }\end{array}$} & \multirow[t]{3}{*}{ Region } & Supply of disposal capacity \\
\hline \multirow[t]{2}{*}{ (end 70s - mid 80s) } & & & Social consensus \\
\hline & & & Economies of scale \\
\hline \multirow{3}{*}{$\begin{array}{l}\text { Prevention and closed } \\
\text { material cycles (90s - ) }\end{array}$} & \multirow{3}{*}{$\begin{array}{l}\text { Minimizing waste flows and } \\
\text { increasing the potential for recovery } \\
\text { of resources }\end{array}$} & National level & \multirow{3}{*}{$\begin{array}{l}\text { Extended producer } \\
\text { responsibility }\end{array}$} \\
\hline & & Manufacturers of goods & \\
\hline & & Retail sector & \\
\hline
\end{tabular}


Table 2 - Main features characterizing waste management regimes

\begin{tabular}{|c|c|c|c|c|c|}
\hline & Early phase & Urban hygiene & End-of-pipe regulation & Transition / emergency & Mature \\
\hline \multirow{3}{*}{$\begin{array}{l}\text { Main institutional } \\
\text { level involved }\end{array}$} & \multirow[t]{3}{*}{ None } & \multirow[t]{3}{*}{ Municipality } & State (legislation, standards) & & \multirow{3}{*}{$\begin{array}{l}\text { State, Region, } \\
\text { Municipality, industrial } \\
\text { associations and } \\
\text { compliance schemes }\end{array}$} \\
\hline & & & Region (planning) & & \\
\hline & & & $\begin{array}{l}\text { Municipality (collection and } \\
\text { management) }\end{array}$ & & \\
\hline \multirow[t]{2}{*}{ Prevalent regime } & \multirow[t]{2}{*}{ Free dumping } & \multirow{2}{*}{$\begin{array}{l}\text { Local monopoly (I) + } \\
\text { free market (II-III) }\end{array}$} & \multirow{2}{*}{$\begin{array}{l}\text { Local monopoly (I) + } \\
\text { environmentally-regulated } \\
\text { free market (II); free market, } \\
\text { but only residual (III) }\end{array}$} & Short-term planning & Dual systems (III) \\
\hline & & & & Dual systems & $\begin{array}{l}\text { Residual monopoly for } \\
\text { collection and first } \\
\text { treatment of MW } \\
\text { (vertical integration I-II) }\end{array}$ \\
\hline \multirow[t]{4}{*}{ Disposal tehniques } & Dumping & Dumping & Controlled landfill & Old facilities & WTE / RDF \\
\hline & Open-air landfill & Open-air incineration & Incineration & Export & Recycling \\
\hline & & Landfill & BMT & $\begin{array}{l}\text { Commercial waste } \\
\text { sector after BMT }\end{array}$ & $\begin{array}{l}\text { Controlled landfill (only } \\
\text { residual and ultimate } \\
\text { waste) }\end{array}$ \\
\hline & & & & & Downcycling \\
\hline Supplier of disposal & Nature & Local market & Public or regulated monopoly & Regulated monopoly & Public, regulated market \\
\hline $\begin{array}{l}\text { Contractual } \\
\text { arrangement I-II }\end{array}$ & None & Market & Planning & $\begin{array}{l}\text { Planning (weakly } \\
\text { regulated market) }\end{array}$ & Vertical integration \\
\hline \multirow{2}{*}{$\begin{array}{l}\text { Role of private } \\
\text { sector }\end{array}$} & & \multirow{2}{*}{$\begin{array}{l}\text { Contractor of low- } \\
\text { skill activities }\end{array}$} & \multirow[t]{2}{*}{ Technology } & \multirow[t]{2}{*}{ Emergency supply } & Long value chain \\
\hline & & & & & Specialized activities \\
\hline \multirow[t]{5}{*}{$\begin{array}{l}\text { Typical private } \\
\text { operator }\end{array}$} & \multirow[t]{5}{*}{ Rag-picker } & $\begin{array}{l}\text { Local SME } \\
\text { (collection) }\end{array}$ & \multirow{5}{*}{$\begin{array}{l}\text { Local or national (I); partner } \\
\text { in PPPs for treatment } \\
\text { facilities; owner of landfill } \\
\text { (national or international } \\
\text { scale) (ii) }\end{array}$} & & Specialized recyclers \\
\hline & & \multirow{4}{*}{$\begin{array}{l}\text { Local SME active in } \\
\text { the construction / } \\
\text { quarrying industry } \\
\text { (landfill) }\end{array}$} & & & Equipment \\
\hline & & & & & Services \\
\hline & & & & & Intermediation \\
\hline & & & & & $\begin{array}{l}\text { Management of selected } \\
\text { flows }\end{array}$ \\
\hline
\end{tabular}


Table 3 - Management of MWM in the OECD

$\begin{array}{lcccccc} & \begin{array}{c}\text { Materials } \\ \text { recovery }\end{array} & \text { MBT } & \text { Incineration, WTE } & & \text { Landfill } & \begin{array}{c}\text { Landfill reduction } \\ 1995-2005\end{array} \\ & \% & \% & \% & \% & \text { Kg/vear/inhab } & \% \\ \text { USA } & 24 \% & 8 \% & 14 \% & \mathbf{5 4 \%} & 407 & -3 \% \\ \text { JPN } & 17 \% & 0 \% & 74 \% & \mathbf{3 \%} & 14 & -8 \% \\ \text { AUT } & 27 \% & 45 \% & 21 \% & \mathbf{7 \%} & 38 & -30 \% \\ \text { BEL } & 31 \% & 23 \% & 34 \% & \mathbf{1 2 \%} & 51 & -36 \% \\ \text { CZ } & 1 \% & 3 \% & 14 \% & \mathbf{8 0 \%} & 223 & \text { n.d. } \\ \text { DK } & 26 \% & 15 \% & 54 \% & \mathbf{5 \%} & 34 & -12 \% \\ \text { SF } & 30 \% & 0 \% & 10 \% & \mathbf{6 0 \%} & 273 & -5 \% \\ \text { FRA } & 16 \% & 14 \% & 34 \% & \mathbf{3 6 \%} & 195 & -9 \% \\ \text { D } & 33 \% & 17 \% & 25 \% & \mathbf{1 8 \%} & 104 & \text { n.d. } \\ \text { GRE } & 8 \% & 0 \% & 0 \% & \mathbf{9 2 \%} & 392 & -1 \% \\ \text { ITA } & 16 \% & 23 \% & 10 \% & \mathbf{5 1 \%} & 294 & -39 \% \\ \text { NL } & 25 \% & 23 \% & 32 \% & \mathbf{2 \%} & 11 & -29 \% \\ \text { NOR } & 34 \% & 15 \% & 25 \% & \mathbf{2 6 \%} & 98 & \text { n.d. } \\ \text { POR } & 9 \% & 6 \% & 21 \% & \mathbf{6 4 \%} & 301 & \text { n.d. } \\ \text { SPA } & 9 \% & 33 \% & 7 \% & \mathbf{5 2 \%} & 277 & -29 \% \\ \text { SWE } & 34 \% & 10 \% & 50 \% & \mathbf{5 \%} & 23 & -30 \% \\ \text { SUI } & 34 \% & 16 \% & 50 \% & \mathbf{1 \%} & 3 & -12 \% \\ \text { UK } & 17 \% & 9 \% & 8 \% & \mathbf{6 4 \%} & 373 & -19 \%\end{array}$


Figure 3 - Public service and market regimes: until landfill dominates (left), and in the post-landfill scenario (right)
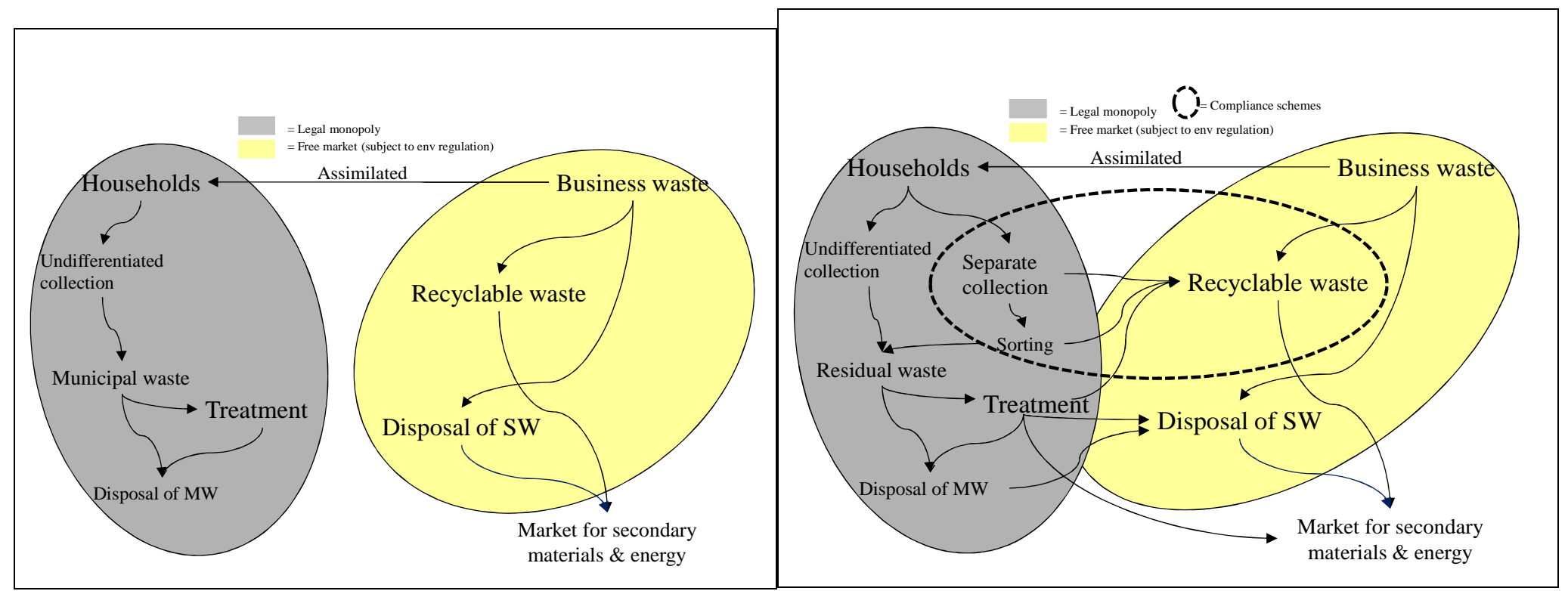
Figure 4 - Alternative ways to organize transactions among the primary, secondary and tertiary market:

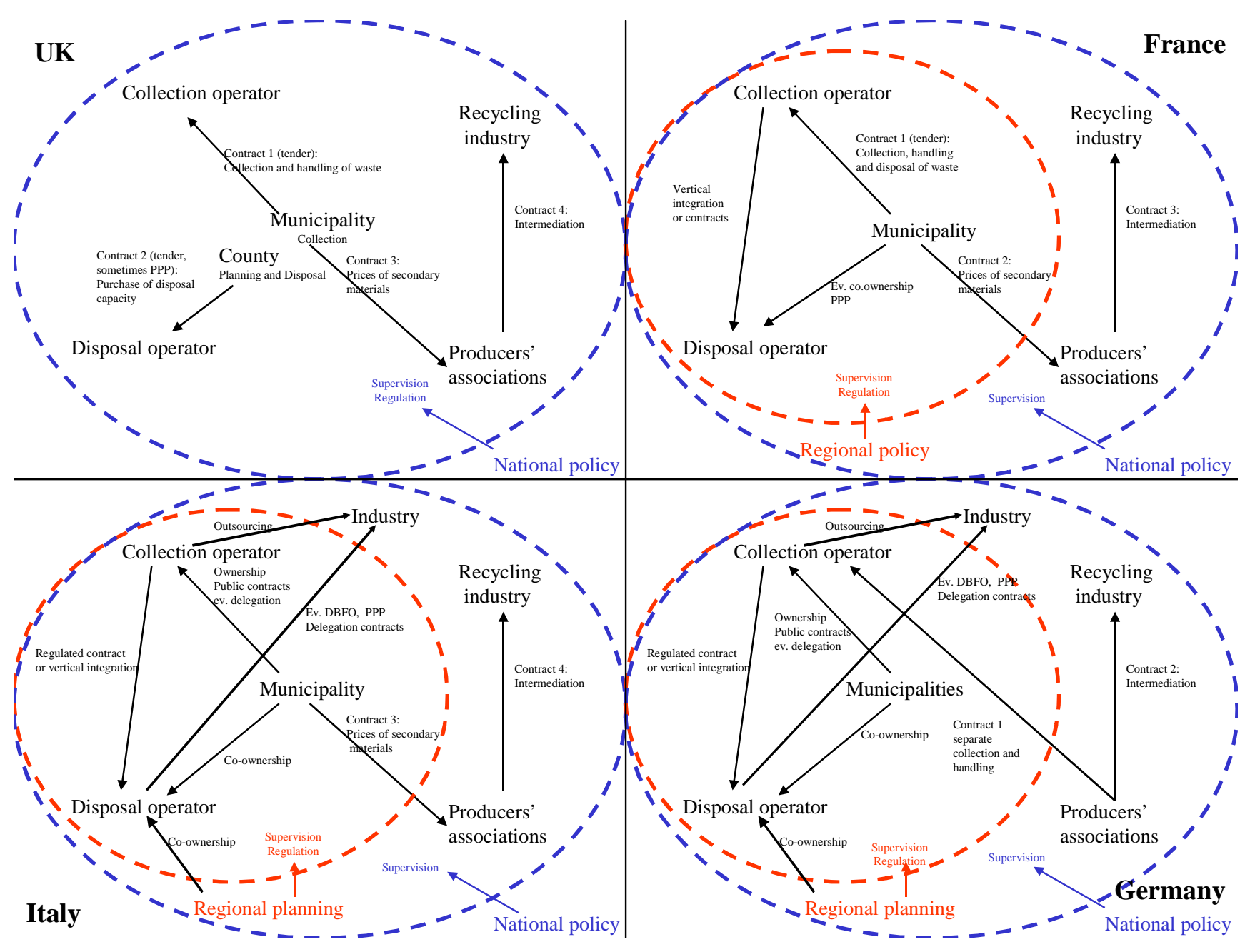


This yearly series of working papers (WP) aims to publish essentially works in English or in French resulting from the scientific network of CIRIEC and more specifically its working groups. The WP are submitted to a review process and are published under the responsibility of the President of the International Scientific Council, the president of the scientific Commissions or the working groups coordinators and of the editor of the CIRIEC international scientific journal, the Annals of Public and Cooperative Economics.

These contributions may be published afterwards in a scientific journal or book.

The contents of the working papers do not involve CIRIEC's responsibility but solely the author(s') one.

The submissions are to be sent to CIRIEC, Université de Liège au Sart Tilman, Bât B33 (bte 6), BE-4000 Liège, Belgique.

Cette collection annuelle de Working Papers (WP) est destinée à accueillir essentiellement des travaux en français ou en anglais issus du réseau scientifique du CIRIEC et en particulier de ses groupes de travail. Les WP font l'objet d'une procédure d'évaluation et sont publiés sous la responsabilité du président du Conseil scientifique international, des présidents des Commissions scientifiques ou des coordinateurs des groupes de travail et de la rédactrice de la revue scientifique internationale du CIRIEC, les Annales de l'économie publique, sociale et coopérative.

Ces contributions peuvent faire l'objet d'une publication scientifique ultérieure.

Le contenu des WP n'engage en rien la responsabilité du CIRIEC mais uniquement celle du ou des auteurs.

Les soumissions sont à envoyer à l'adresse du CIRIEC, Université de Liège au Sart Tilman, Bât B33 (bte 6), BE-4000 Liège, Belgique. 


\section{Publications}

2011/01 Maintaining Local Transport Services in Japan

Fumitoshi MIZUTANI \& Shinichi SAITO

2011/02 Water Supply Utility Businesses in Japan

Shoji KUSUDA

2011/03 Municipal Solid Waste Management in Japan - Present Situation and Characteristics

Naohisa WADA

2011/04 La gestion intégrée des déchets solides en Algérie. Contraintes et limites de sa mise en oeuvre

Brahim DJEMACI \& Malika AHMED ZAÏD-CHERTOUK

2011/05 Local public services: Facts, experiences and prospects Water services: what are the main challenges?

Synthesis report

Pierre BAUBY

2011/06 Local public services: Facts, experiences and prospects

New organizational models in European Local Public Transport:

from Myth to Reality.

Andrea ZATTI

Synthesis report

2011/07 Local public services: Facts, experiences and prospects

The municipal waste management sector in Europe: shifting boundaries between public service and the market. Synthesis report Barbara ANTONIOLI \& Antonio MASSARUTTO 
CIRIEC (International Centre of Research and Information on the Public, Social and Cooperative Economy) is a non governmental international scientific organization.

Its objectives are to undertake and promote the collection of information, scientific research, and the publication of works on economic sectors and activities oriented towards the service of the general and collective interest: action by the State and the local and regional public authorities in economic fields (economic policy, regulation); public utilities; public and mixed enterprises at the national, regional and municipal levels; the so-called "social economy" (not-for-profit economy, cooperatives, mutuals, and non-profit organizations); etc.

In these fields CIRIEC seeks to offer information and opportunities for mutual enrichment to practitioners and academics and for promoting international action. It develops activities of interest for both managers and researchers.
Le CIRIEC (Centre International de Recherches et d'Information sur l'Economie Publique, Sociale et Coopérative) est une organisation scientifique internationale non gouvernementale.

Ses objectifs sont d'assurer et de promouvoir la collecte d'informations, la recherche scientifique et la publication de travaux concernant les secteurs économiques et les activités orientés vers le service de l'intérêt général et collectif : l'action de l'Etat et des pouvoirs publics régionaux et locaux dans les domaines économiques (politique économique, régulation); les services publics; les entreprises publiques et mixtes aux niveaux national, régional et local ; l'économie sociale : coopératives, mutuelles et associations sans but lucratif ; etc.

Le CIRIEC a pour but de mettre à la disposition des praticiens et des scientifiques des informations concernant ces différents domaines, de leur fournir des occasions d'enrichissement mutuel et de promouvoir une action et une réflexion internationales. Il développe des activités qui intéressent tant les gestionnaires que les chercheurs scientifiques.

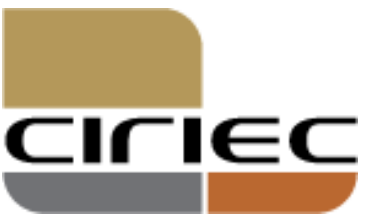

International Centre of Research and Information on the Public, Social and Cooperative Economy - aisbl Centre international de Recherches et d'Information sur l'Economie Publique, Sociale et Coopérative - aisbl

Université de Liège au Sart-Tilman

Bât. B33 - bte 6

BE-4000 Liège (Belgium)
Tel. : $+32(0) 43662746$ Fax : $+32(0) 43662958$ E-mail : cinec@ulg.ac.be http://www.cinec.ulg.ac.be 